\title{
Anthropometric Characteristics, Body Composition and Somatotype of Elite Pan-American Race Walking 20K
}

\author{
Características Antropométricas, Composición Corporal y \\ Somatotipo de Marchistas Panamericanos de Élite 20k
}

\author{
Espinoza-Navarro, O. ${ }^{1}$; Lizana, P. A. ${ }^{2}$; Gómez-Bruton, A. ${ }^{3}$; Brito-Hernández, L. ${ }^{4}$ \& Lagos-Olivos C. ${ }^{5}$
}

ESPINOZA-NAVARRO, O.; LIZANA, P. A.; GÓMEZ-BRUTON, A.; BRITO-HERNÁNDEZ, L. \& LAGOS-OLIVOS, C. Anthropometric characteristics, body composition and somatotype of elite Pan-American race walking 20K. Int. J. Morphol., 37(4): 12201225, 2019.

SUMMARY: The anthropometric and somatotype evaluation is an essential tool in the selection and control of high-performance athletes. The aim of this study was to describe the somatotype and body composition of male elite race walkers ( $20 \mathrm{k}$ modality), and its relationship with athletic performance. Twenty-four race walkers participated in this study. The sample was divided into two groups: the race walkers with the best performance (upper 25 percentile; $n=7)$ and the second group $(n=17)$ that corresponds to the rest of the participants. Weight $(\mathrm{kg})$, height $(\mathrm{cm})$, seven skinfolds, two diameters and five perimeters were measured. Body fat percentage (BF\%) were estimated with the Yuhasz formula, and the somatotype was used applying the Heath-Carter method. The best performing athletes were taller $(178.3 \pm 4.4 \mathrm{~cm}$ vs. $173.7 \pm 5.6 \mathrm{~cm}, \mathrm{p}<0.05)$ and showed a greater ectomorphic component $(\mathrm{p}<0.05)$ than the rest of the participants. The somatotype of the best performance athletes was 2.2-2.8-4.1 against the 2.5-3.8-2.9 of the lowest performing athletes. The average time (hours, minute, seconds) of execution of the race in athletes of better performances was 1:22:40, in comparison with the athletes of lower performances with 1:32:41 ( $<<0.02)$. The ectomorphic component and height are morphological characteristics that can determine athletic performance of race walkers. It is suggested to consider these factors in the selection of the race walkers.

KEY WORDS: Race walking; Somatotype; Ectomorphy; Athletics; Anthropometry.

\section{INTRODUCTION}

Athletic race walking is an Olympic discipline that is characterized by a technique that subjects the foot to a great effort in its execution, where there is no flight phase, that is, the walker must never lose contact with the ground (IAAF, 2016). This athletic modality is considered a long distance discipline, which requires superior resistance and technical ability (Vernillo, 2013; Hanley et al., 2014; Hanley et al., 2015; Gómez-Ezeiza et al., 2016). The appearance of great world figures in some regions makes it increasingly popular on all continents (Larsen, 2003; Vernillo; Wilber \& Pitsiladis, 2012).

Nonetheless, the anthropometric reports of elite race walkers are scarce. Previous studies have reported that female race walkers have a higher percentage of body fat, greater endomorphic component and lower muscle mass than male athletes (Gamboa et al., 2018; Gómez-Ezeiza et al., 2018). Furthermore, male race walkers have shown low rates of body fat and a predominant ectomorphic component in previous studies (Larsen \& Sheel, 2015; Gamboa et al.). When comparing distances, a greater mesomorphic component was found in $20 \mathrm{k}$ athletes when compared to 50k athletes (Gomez-Ezeiza et al., 2016). However, it remains unknown if there are anthropometric characteristics that are associated with a higher athletic performance among elite $20 \mathrm{k}$ race walkers.

One of the best factors to determine adiposity is anthropometry, which has been standardized by the International Society for the Advancement of Kinanthropometry (ISAK, 2001) so that it is reliable, reproducible, valid and accurate (Marfell-Jones et al., 2006).

\footnotetext{
${ }^{1}$ Laboratory of Reproduction and Development, Department of Biology, Universidad de Tarapacá, Arica, Chile.

${ }^{2}$ Laboratory of Morphological Sciences, Instituto de Biología, Pontificia Universidad Católica de Valparaíso, Valparaíso, Chile

${ }^{3}$ Growth, Exercise, Nutrition and Development (GENUD) Research Group, University of Zaragoza. Zaragoza, Spain.

${ }^{4}$ Laboratorio Biología de Reproducción y Desarrollo, Programa Magíster Ciencias de la Motricidad Humana, Universidad de Tarapacá, Arica-Chile.

${ }_{5}^{5}$ Departamento de Ciencias de la Actividad Física y del Deporte, Universidad de Tarapacá, Arica-Chile.
} 
The Heath-Carter method which is performed with the aforementioned anthropometric measurements, classifies individuals by its three essential elements, endomorphy or first component (relative adiposity), mesomorphy or second component (tendency to relative musculoskeletal development) and ectomorphy or third component (tendency to relative linearity) which results in the somatotype or biotype of a person. This is an anthropometric method that has had an essential relevance in the classification of athletes and non-athletes (Olguín et.al., 2013; Busko et al., 2013; Lizana et al., 2015; Gamboa et al.; Gomez-Ezeiza et al.; Lizana et al., 2018a; Lizana et al., 2018b).

In this sense, the aim of the present investigation was to determine the differences in somatotype and adiposity in elite $20 \mathrm{k}$ race walkers according to sports performance.

\section{MATERIAL AND METHOD}

This was a cross-sectional study in which anthropometric characteristics were compared between upper and lower performance race walkers. The participants comprised male athletes who competed in the Pan-American race walking cup in the 20k event (XVII Pan-American March Cup, Arica-Chile, 2015).

For this study, all athletes were invited to participate before the competition. Those athletes who agreed to participate and who completed the whole evaluation $(n=24)$ were included in the study. One athlete was excluded for not presenting complete data. Athletes from 10 different nationalities were included in the present study.

The athletes were evaluated two days before the competition, during the morning session. Weight and height were measured with Detecto model 2391 (Detecto, Webb City, NY, USA) of $0.1 \mathrm{~kg}$ and $0.1 \mathrm{~cm}$ of precision respectively. With the variables of weight and height, the body mass index (weight in kilograms divided by the square of height in meters) was determined. The percentage of body fat (BF \%) for males was recorded through the Yuhasz equation: $\mathrm{BF} \%=(\Sigma 6$ skinfolds $\mathrm{x} 0.1051)+2.58$ (Yuhasz, 1974), which incorporates six skinfolds (triceps, subscapular, supraspinal, abdominal, anterior thigh and medial calf), the Yuhaz equation was chosen because it was used with and for athletes (Carter, 1982). The skinfolds, perimeters, and diameters were determined with the Rosscraft anthropometric set (Rosscraft, Surrey, Canada). All the variables were measured on the right side of the body of the athletes.
For the evaluation of the anthropometric somatotype the Heath-Carter method was used, which comprises two primary measures: weight and height, four skinfolds (triceps, subscapular, supraspinal, and medial calf), two bone diameters (biepicondylar humeral and femoral) and two perimeters (arm flexed and in maximum tension and maximum leg perimeter). From the measurements, the three components of the somatotype (endomorphy, mesomorphy, and ectomorphy) were determined. To calculate the difference between two somatotypes, the somatotype dispersion distance (SDD) was used, using the equation SDD $=\sqrt{ }(3(\mathrm{X} 1-\mathrm{X} 2) 2+(\mathrm{Y} 1-\mathrm{Y} 2) 2)$, this is a measure of dispersion; this distance is statistically significant at $\mathrm{p}<0.05$, when SDD is equal to or greater than 2 (Hebbelincket et al., 1975). The sample was also represented through a somatochart and to describe the categories of the somatotype the thirteen categories proposed by Carter were defined (Carter \& Heath, 1990).

Evaluations were performed with the athletes standing in bare feet and wearing light clothes. Anthropometric measurements were taken at the right hemibody. The measurements were made following the standardized protocols of the International Society for Advancement of Kineanthropometry (Marfell-Jones et al., 2006). The technical error of measurement of the evaluator (ENO) was less than $3 \%$ for skinfolds and less than $1 \%$ for other anthropometrics measurements. The Ethics Committee of the Universidad de Tarapacá, Chile, approved the work protocols following the Helsinki Declaration.

Statistical analysis. All the obtained data were processed with the statistical package STATA 12 (Stata, College Station. TX) software. The inspection of normality before the analyzes was performed with the Shapiro Wilk test. The results were expressed in frequency, average, and standard deviation. The sample was separated into two groups: the p25 with the best performances $(n=7)$ and the rest of the athletes $(n=17)$. The Mann-Whitney test was performed to compare both groups. The level of significance used was $\mathrm{p}<0.05$.

\section{RESULTS}

Table I describes the characteristics of the sample, according to age, height and weight, as well as skinfolds, diameters and body perimeters. Athletes whit better performance were taller $(\mathrm{p}<0.05)$. Moreover, high performance athletes presented lower triceps skinfolds and a smaller femoral diameter $(\mathrm{p}<0.05)$. A tendency to lower BMI was also observed in high-performance athletes $(p=0.06)$. 
Table I. Descriptive anthropometric characteristics of elite race walkers (20 kilometers). Arica, Chile. May $2015(\mathrm{n}=24)$

\begin{tabular}{|c|c|c|c|c|c|c|c|}
\hline \multirow[b]{2}{*}{ Variable } & \multicolumn{2}{|c|}{ Total sample } & \multicolumn{2}{|c|}{ Best performance } & \multicolumn{2}{|c|}{ Low performance } & \multirow[b]{2}{*}{ p-value } \\
\hline & Mean & SD & Mean & SD & Mean & SD & \\
\hline Age (years) & 23.30 & 4.60 & 23.29 & 3.35 & 23.24 & 5.12 & 0.823 \\
\hline Height (cm) & 175.04 & 5.58 & 178.29 & 4.42 & 173.71 & 5.55 & 0.033 \\
\hline Weight (kg) & 65.48 & 5.93 & 63.99 & 5.34 & 66.09 & 6.21 & 0.341 \\
\hline \multicolumn{8}{|l|}{ Personal best } \\
\hline \multicolumn{8}{|l|}{ Skinfolds (mm) } \\
\hline Biceps & 4.18 & 1.01 & 3.71 & 0.76 & 4.36 & 1.05 & 0.147 \\
\hline Triceps & 7.7 & 3.81 & 5.43 & 1.99 & 8.64 & 4.03 & 0.021 \\
\hline Subscapular & 8.52 & 2.29 & 8.71 & 3.04 & 8.44 & 2.01 & 0.725 \\
\hline Abdominal & 11.60 & 4.77 & 9.86 & 5.76 & 12.27 & 4.30 & 0.127 \\
\hline Supraspinal & 9.2 & 4.22 & 9.71 & 5.28 & 8.99 & 3.88 & 0.873 \\
\hline Front thigh & 9.11 & 4.28 & 7.71 & 2.29 & 9.68 & 4.82 & 0.278 \\
\hline Medial calf & 6.83 & 3.73 & 5.43 & 2.37 & 7.40 & 4.09 & 0.209 \\
\hline \multicolumn{8}{|l|}{ Breadths (cm) } \\
\hline Humeral & 7.12 & 0.75 & 7.27 & 1.37 & 7.06 & 0.29 & 0.370 \\
\hline Femur & 9.68 & 0.63 & 9.14 & 0.93 & 9.90 & 0.27 & 0.004 \\
\hline \multicolumn{8}{|l|}{ Perimeters (cm) } \\
\hline Upper arm & 25.44 & 1.96 & 25.36 & 2.63 & 25.48 & 1.71 & 0.873 \\
\hline Upper arm tensed & 28.43 & 2.01 & 28.46 & 1.95 & 28.42 & 2.10 & 0.900 \\
\hline Waist & 74.71 & 5.08 & 74.16 & 5.63 & 74.94 & 5.01 & 0.373 \\
\hline Hip & 88 & 4.52 & 86.57 & 4.04 & 88.59 & 4.69 & 0.265 \\
\hline Calf (maximum) & 33.70 & 2.15 & 33.11 & 3.13 & 33.87 & 1.67 & 0.179 \\
\hline \multicolumn{8}{|l|}{ Body composition } \\
\hline Body mass index & 21.40 & 2.02 & 20.15 & 1.74 & 21.91 & 1.93 & 0.061 \\
\hline Percentage of $\mathrm{BF}^{\mathrm{a}}$ & 8.15 & 1.81 & 7.54 & 2.01 & 8.40 & 1.71 & 0.153 \\
\hline$\sum$ of six skinfolds & 52.92 & 16.99 & 46.86 & 18.34 & 55.41 & 16.31 & 0.162 \\
\hline \multicolumn{8}{|l|}{ Somatotype $^{\mathrm{b}}$} \\
\hline Endomorphy & 2.45 & 0.83 & 2.22 & 1.01 & 2.54 & 0.76 & 0.153 \\
\hline Mesomorphy & 3.51 & 1.22 & 2.82 & 1.63 & 3.79 & 0.92 & 0.136 \\
\hline Ectomorphy & 3.26 & 1.17 & 4.09 & 1.04 & 2.92 & 1.07 & 0.028 \\
\hline
\end{tabular}

$\mathrm{SD}$, Standard deviation. *Mann-Whitney test for comparison of all variables were used. aPercentage fat was estimated according to Yuhasz's equation.

bThe Heath-Carter anthropometric method was used for somatotyping.
Concerning somatotype, high performance athletes showed significant higher values for the ectomorphic component versus their lower performance peers $(\mathrm{p}<0.05)$. In addition, the SDD shows differences between the p25 (best performance) and the rest of the subjects $(\mathrm{SDD}=3.80)$

Table II shows the distribution of the somatotype categories according to those proposed by Carter \& Heath. It is reported that the balanced ectomorph category predominates in the high performance athletes $(43 \%)$ and the categories mesomorphectomorph $(23.53 \%)$ and ectomorphic mesomorph $(23.53 \%)$ predominate in athletes with the lowest performance.

Figure 1 shows the distribution of the somatotypes of elite race walkers $20 \mathrm{~K}$. Gray circles represent the best performance athletes (p25). Black circles represent the rest of the athletes. White circle indicates the average somatotype of the sample: 2.5- 3.5- 3.3. White square suggests the group of athletes with the best performance 2.2-2.8-4.1 and black square indicates the rest of group 2.5-3.8-2.9. Black triangle represents the average somatotype of race walking according to Canda and black square represents the average somatotype of race walkers according Gomez-Ezeiza et al.

\begin{tabular}{lrrr}
\hline Somatotype categ ories & Male (n 24) & Best performance & Low performance \\
\hline 1. Balanced endomorph & $0(0)$ & $0(0)$ & $0(0)$ \\
2. Mesomorphic endomorph & $0(0)$ & $0(0)$ & $0(0)$ \\
3. Mesomorph-endomorph & $12.50(3)$ & $14.29(1)$ & $11.76(2)$ \\
4. Endomorphic mesomorph & $12.50(3)$ & $0(0)$ & $17.65(3)$ \\
5. Balanced mesomorph & $4.17(1)$ & $0(0)$ & $5.88(1)$ \\
5. Ectomorphic mesomorph & $\mathbf{2 0 . 8 3 ( 5 )}$ & $14.29(1)$ & $\mathbf{2 3 . 5 3 ( 4 )}$ \\
7. Mesomorph-ectomorph & $\mathbf{2 0 . 8 3 ( 5 )}$ & $14.29(1)$ & $\mathbf{2 3 . 5 3 ( 4 )}$ \\
3. Mesomorphic ectomorph & $4.17(1)$ & $0(0)$ & $5.88(1)$ \\
9. Balanced ectomorph & $16.67(4)$ & $\mathbf{4 2 . 8 6 ( 3 )}$ & $5.88(1)$ \\
10. Endomorphic ectomorph & $4.17(1)$ & $14.29(1)$ & $0(0)$ \\
11. Endomorph-ectomorph & $0(0)$ & $0(0)$ & $0(0)$ \\
12. Ectomorphic endomorph & $0(0)$ & $0(0)$ & $0(0)$ \\
13. Central & $4.17(1)$ & $0(0)$ & $5.88(1)$ \\
\hline
\end{tabular}

Table II. Distribution of 13 somatotype categories among race walkers (20 kilometers). Arica, Chile. May 2015 ( $n=24)$.

Values are expressed as percentage and frequency (). Bold values indicate high prevalences. 


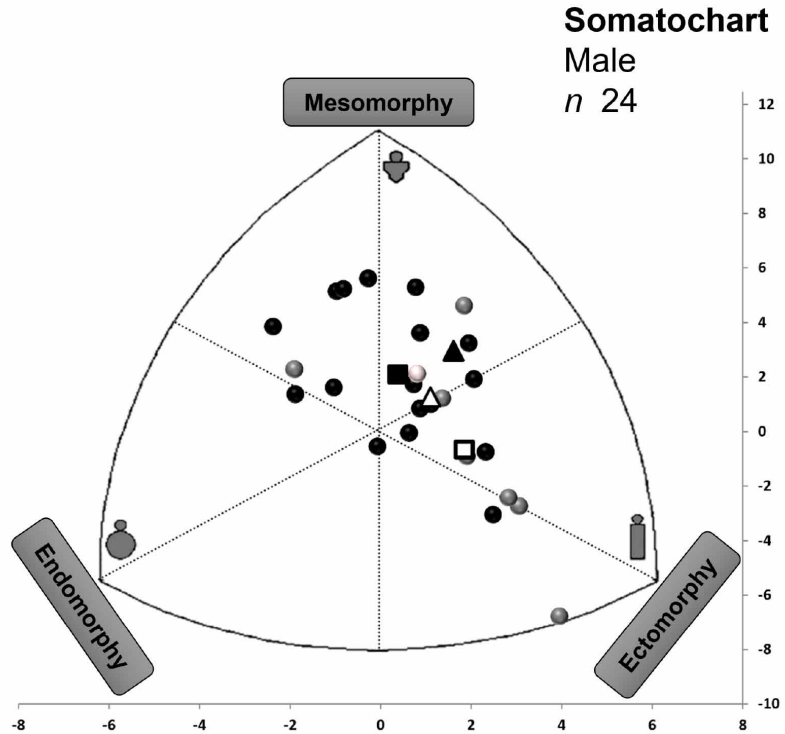

Fig. 1. Distribution of individual somatopoints of the male elite race walkers. Gray circles represent the best performance athletes (p25). Black circles represent the rest of the athletes. White circle somatotype of the sample: 2.5 - 3.5- 3.3. White square best performance 2.2-2.8-4.1. Black triangle somatotype of race walkers according to Canda (2012). Black square represents the average somatotype of race walkers $20 \mathrm{k}$ according to Gomez-Ezeiza at al. (2018).

\section{DISCUSSION}

The search for athletes who have the right anthropometric characteristics to compete successfully at the highest level is increasingly difficult. Anthropometry and somatotype are methods that report on the most predominant physical characteristics of athletes (Rodríguez Quijada, 2016; Giannopoulous et al., 2017). Several authors using these methods have previously noticed the importance of height and adiposity levels in sports performance (Carter; Carter and Heath; Knechtle et al., 2010). However different athletic disciplines have distinct morphological characteristics, such as long upperlimbs in rowing, greater endomorphy in throwing sports and higher ectomorphy in long-distance races (Kerr et $a l$; Yáñez-Sepúlveda et al, 2018). When analyzing the anthropometric characteristics of the studied sample, it was observed that high performance athletes were taller, which could give them an advantage in the length of the step that they execute during the race. In this regard, Hanley et al., (2011), reported differences in walking speed between males and females, in the $10 \mathrm{k}$ and $20 \mathrm{k}$ modalities, for the range of the step at the same rate indicating that the initial cause of deceleration was the reduction in the length of the step (Hanley et al., 2011;
Hanley et al., 2014), aspect that was also observed in 50k race walkers (Hanley et al., 2013). It has also been reported that Kenyan distance athletes have $5 \%$ longer lower limbs when compared to elite Scandinavian distance runners (Wilber \& Pitsiladis), so a higher height could be an advantage in long distance running/walking events.

Concerning the somatotype of our sample, it is observed that the athletes have a predominantly mesomorphectomorph somatotype, which corresponds to similar mesomorph and ectomorph components with the endomorph being less predominant. Eiin et al. (2007), describe the somatotype of young Malaysian distance athletes, finding in men an average somatotype similar to our results from the total sample with greater mesomorph and ectomorph components, also reported by Canda in Spanish race walkers. However, when dividing the groups, the high performance group shifts towards the balanced ectomorphism and the low performance towards a balanced mesomorphism. Additionally, these results are consistent with the significant differences in SDD among the groups studied. Kandel et $a l$., evaluated the performance of Ironman athletes, observing that a low endomorphic component combined with a high ectomorphic component result in a significantly better performance. Besides the authors emphasize that the somatotype had a larger impact on the running discipline and these results were those of men since the same findings were not found in females. These results are similar to those found in our study due to lower values associated with adiposity (BF \%, $\Sigma$ of six skinfolds, and endomorphy, not significant) and a greater ectomorph component. In this sense, a marked ectomorph component is observed in marathon athletes over mesomorphism and endomorphism (Vernillo, 2013). Furthermore, a characteristic element of Kenyan distance runners is their ectomorphic somatotype, which have been highlighted by essential sporting achievements in recent decades (Larsen \& Sheel).

Additionally, some authors report an important relationship between the thickness of the skinfolds of the thigh and leg and the performance in long distance events (Arrese \& Ostariz, 2006), in our study we observed smaller skinfolds in athletes of better performance. However, these differences between groups were not significant. Although, we found a trend that is relevant to continue studying in elite race walkers. Another component frequently mentioned in sports practice is the $\mathrm{BF} \%$ that has been related to performance (Knechtle et al.). Our group presented $8.2 \% \mathrm{BF}$, while the high performance showed a $7.5 \% \mathrm{BF}$, similar of that reported by Gomez-Ezeiza et al. with a $6.8 \%$ BF. Employing the same formulas for BF \% as our study, Gamboa et al., reported a $7.64 \mathrm{BF} \%$ in $10 \mathrm{~K}$ race walkers, a value that was similar to that of the highest performing $20 \mathrm{~K}$ athletes. 
Limitations. On the one hand the sample of athletes is small, but they are elite race walking of a Pan-American championship and therefore the whole sample that could be measured was also small. Another limitation was that the sample studied is very heterogeneous (ten different nationalities) with different ethnic groups that could influence the biotype of the subjects. On the other hand, because it is a cross-sectional study by its nature, it is not possible to determine cause-effect, so future studies are needed to corroborate the findings.

\section{CONCLUSIONS}

The ectomorph component and height are morphological characteristics that could be associated with athletic performance of $20 \mathrm{k}$ elite race walkers. It is suggested to consider these factors in the selection of high-performance race walkers.

ESPINOZA-NAVARRO, O.; LIZANA, P. A.; GÓMEZBRUTON, A.; BRITO-HERNÁNDEZ, L.\& LAGOS-OLIVOS, C. Características antropométricas, composición corporal y somatotipo de marchistas panamericanos de élite 20k. Int. J. Morphol., 37(4):1220-1225, 2019.

RESUMEN: La evaluación antropométrica y del somatotipo es una importante herramienta en la selección y control de los atletas de alto rendimiento. El objetivo de este estudio fue describir el somatotipo y composición corporal de hombres marchistas olímpicos, modalidad 20 k, y su relación con el rendimiento atlético. Veinticuatro atletas de marcha participaron en este estudio. La muestra fue dividida en dos grupos: los marchistas de mejores rendimientos p25 superior $(n=7)$ y el segundo grupo $(\mathrm{n}=17)$ que corresponde al resto de los participantes. Se registró el peso $(\mathrm{kg})$, talla $(\mathrm{cm})$, siete pliegues cutáneos, dos diámetros y cinco perímetros. Se estimó el porcentaje de grasa corporal (\%GC) con la fórmula de Yuhasz y se describió el somatotipo utilizando el método de Heath-Carter. Se reporta una mayor altura en los atletas de mejor rendimiento $(178,3 \pm 4,4 \mathrm{~cm}$ vs. $173,7 \pm 5,6 \mathrm{~cm}$; $\mathrm{p}<0,05)$ y mayor componente ectomorfico $(\mathrm{p}<0,05)$ que el resto de los participantes. El somatotipo de los atletas de mejor rendimiento fue de 2.2-2.8-4.1 frente al 2.5-3.8-2.9 de los atletas de menor rendimiento. El tiempo promedio (hora, minuto, segundo) de ejecución de la carrera en atletas de mejores rendimientos fue de 1:22:40, en comparación con los atletas de menores rendimientos con 1:32:41 ( $\mathrm{p}<0,02)$. El componente ectomórfico y altura serian características morfológicas que pueden determinar el rendimiento deportivo de atletas de marcha. Se sugiere considerar estos factores en la selección de los marchistas olímpicos.

PALABRAS CLAVE: Marchistas; Somatotipo; Ectomorfismo; Atletas; Antropometría.

\section{ACKNOWLEDGMENTS}

This work was funded by the project UTA Major $\mathrm{N}^{\circ}$ 4716-17, Universidad de Tarapacá, Arica-Chile. The authors thank the Dirección de Investigación, Vice-Rectoría de Investigación y Estudios Avanzados and the Instituto de Biología, Facultad de Ciencias de la Pontificia Universidad Católica de Valparaíso, Chile and Dr. Jorge Díaz Gamboa for the signing of athletes.

\section{REFERENCES}

Arrese, A. L. \& Ostáriz, E. S. Skinfold thicknesses associated with distance running performance in highly trained runners. J. Sports Sci., 24(1):69-76, 2006.

Busko, K.; Pastuszak, A.; Lipinska, M.; Lipinska, M. \& Gryko, K. Somatotype variables related to strength and power output in male basketball players. Acta Bioeng. Biomech., 19(2):161-7, 2017.

Canda, A. Variables Antropométricas de la Población Deportista Española. Madrid, Colección ICD, Consejo Superior de Deportes, 2012.

Carter, J. \& Heath, B. Somatotyping Development and Applications. New York, Cambridge University Press, 1990.

Carter, J. E. L. Body Composition of Montreal Olympic Athletes. In: Carter, J. E. L. (Ed.). Physical Structure of Olympic Athletes. Part I. Montreal Olympic Games. Basel, Karger, 1982. pp.107-16.

Eiin, W. J.; Flyger, N. \& Wilson, N. Somatotypes of young malaysian track and field athletes. Asian J. Exerc. Sports Sci., 4(1):1-7, 2007.

Gamboa, D. J.; Espinoza-Navarro, O.; Brito-Hernández, L.; GómezBruton, A. \& Lizana, P. A. Body composition and somatotype of elite 10 kilometers race walking athletes. Interciencia, 43(4):28994,2018

Giannopoulos, N.; Vagenas, G.; Noutsos, K.; Barzouka, K. \& Bergeles, N. Somatotype, level of competition, and performance in attack in elite male volleyball. J. Hum. Kinet., 58:131-40, 2017.

Gomez-Ezeiza, J.; Granados, C. \& Santos-Concejero, J. Different competition approaches in a world-class 50-km racewalker during an Olympic year. J. Sports Med.Phys. Fitness, 56(11):1423-7, 2016.

Gomez-Ezeiza, J.; Tam, N.; Torres-Unda, J.; Granados, C. \& SantosConcejero, J. Anthropometric characteristics of top-class Olympic race walkers. J. Sports Med. Phys. Fitness, 59(3):429-33, 2018.

Hanley, B. Gait alterations during constant pace treadmill racewalking. J. Strength Cond. Res., 29(8):2142-7, 2015.

Hanley, B.; Bissas, A. \& Drake, A. Kinematic characteristics of elite men's and women's $20 \mathrm{~km}$ race walking and their variation during the race. Sports Biomech., 10(2):110-24, 2011.

Hanley, B.; Bissas, A. \& Drake, A. Kinematic characteristics of elite men's 50 km race walking. Eur. J. Sport Sci., 13(3):272-9, 2013.

Hanley, B.; Bissas, A. \& Drake, A. Technical characteristics of elite junior men and women race walkers. J. Sports Med. Phys. Fitness, 54(6):700-7, 2014.

Hebbelinck, M.; Carter, J. E. L. \& De Garay, A. A Body Build and Somatotype of Olympic Swimmers. En: Lewille, L. \& Clarys, J. P. (Eds.). Swimming. Vol. II. Baltimore, University of Park Press, 1975.

Henríquez-Olguín, C.; Báez, E.; Ramírez-Campillo, R. \& Cañas, R. Somatotype profile of professional male soccer chilean players. Int . J. Morphol., 31(1):225-30, 2013.

International Association of Athletics Federations (IAAF). Competition Rules 2016-2017. Monte Carlo, Imprimerie Multiprint, 2016. 
Kandel, M.; Baeyens, J. P. \& Clarys, P. Somatotype, training and performance in Ironman athletes. Eur. J. Sport. Sci., 14(4):301-8, 2014.

Kerr, D. A.; Ackland, T. R. \& Schreiner, A. B. The elite athlete - assessing body shape, size, proportion and composition. Asia Pac. J. Clin. Nutr., 4(1):25-9, 1995

Knechtle, B.; Wirth, A.; Baumann, B.; Knechtle, P. \& Rosemann, T. Personal best time, percent body fat, and training are differently associated with race time for male and female ironman triathletes. Res. Q. Exerc. Sport., 81(1):62-8, 2010.

Larsen, H. B. \& Sheel, A. W. The Kenyan runners. Scand. J. Med. Sci. Sports, 25(S4):110-8, 2015.

Larsen, H. B. Kenyan dominance in distance running. Comp. Biochem. Physiol. A Mol. Integr. Physiol., 136(1):161-70, 2003.

Lizana, P. A.; González, S.; Lera, L. \& Leyton, B. Association between body composition, somatotype and socioeconomic status in chilean children and adolescents at different school levels. J. Biosoc. Sci., 50(1):53-69, 2018a.

Lizana, P. A.; Olivares, R. \& Berral, F. J. Somatotype tendency in Chilean adolescents from Valparaíso: review from 1979 to 2011. Nutr. Hosp., 31(3):1034-43, 2014.

Lizana, P. A.; Simpson, M. C.; Farias, P. \& Berral, F. J. Somatotypes of schoolchildren from Chile: higher endomorphic components among adolescent girls. Nutr. Hosp., 35(5):1033-41, 2018 b.

Marfell-Jones, M.; Olds, T.; Stewart, A. \& Carter, L. International Standards For Anthropometric Assessment. Potchefstroom, International Society for the Advancement of Kinanthropometry, 2006.

Rodríguez Quijada, M. El deportista de éxito, ¿nace o se hace?. Una revisión bibliográfica. Apunts Educ. Fis. Deportes, 1(123):13-8, 2016.

Vernillo, G.; Schena, F.; Berardelli, C.; Rosa, G.; Galvani, C.; Maggioni, M.; Agnello, L. \& La Torre, A. Anthropometric characteristics of topclass Kenyan marathon runners. J. Sports Med. Phys. Fitness, 53(4):403-8, 2013.

Wilber, R. L. \& Pitsiladis, Y. P. Kenyan and Ethiopian distance runners: what makes them so good? Int. J. Sports Physiol. Perform., 7(2):92$102,2012$.

Yáñez-Sepúlveda, R.; Díaz-Barrientos, S.; Montiel-González, S. \& ZavalaCrichton, J. P. Anthropometric characteristics, body composition and somatotype in elite junior ITF tennis players from South America. Int. J. Morphol., 36(3):1095-100, 2018.

Yuhasz, M. Physical Fitness and Sports Appraisal Laboratory Manual. London (Canada), University of Western Ontario, 1974.
Corresponding author:

Prof. Dr. Omar Espinoza Navarro

Facultad de Ciencias Departamento de Biología

Universidad de Tarapacá

Avenida. General Velásquez N 1775

Arica

CHILE

Email: omarespinoza091@gmail.com

Recibido : 12-06-2019

Aceptado: 11-07-2019 